\title{
Creating Sustainable Photovoltaics for Smart Cities
}

\author{
Werner Brenner \\ TU Wien, Institute of Sensor and Actuator Systems, Austria \\ Nadja Adamovic \\ TU Wien, Institute of Sensor and Actuator Systems, Austria
}

\begin{abstract}
Research on solar energy systems and materials has yielded promising opportunities for sustainable energy solutions, which do not only consider environmental issues but also allow aesthetic design possibilities. New requirements regarding the energy efficiency performance of buildings gave the basis for two European projects aiming at sustainable energy solutions, which consider both environmental issues and aesthetic design. All research findings were expected to be in line with the EU's Waste Electrical and Electronic Equipment (WEEE) directive. FP7 SolarDesign put a focus on novel printing and scribing methods which make possible the manufacturing of flexible monolithically interconnected photovoltaic modules to be integrated into both devices and building envelopes. This technology allows customization of the PV modules' shape, size and voltage. SolarDesign developed a solar foil with a width of $300 \mathrm{~mm}$, basis for curved solar cells with a minimum radius of $10 \mathrm{~mm}$. The $\mathrm{H} 2020$ project CABRISS contributes to a circular economy that manages the critical situation of recycling a significant volume of photovoltaic waste. The project also contributes to electronics, metallurgy and glass industries. CABRISS comprises the development of: (i) recycling technologies to recover $\mathrm{In}, \mathrm{Ag}$ and $\mathrm{Si}$, (ii) demonstrating the possibility for the re-usability and recyclability of end-of-life key PV materials. Both projects involved European standardization bodies (CEN/CENELEC, SEMI).
\end{abstract}

Keywords: photovoltaics PV, circular economy, standardization, innovation, technology, sustainability, smart cities

JEL classification: $\mathrm{O32}$

Acknowledgments: FP7 SolarDesign has received funding from the EU under grant agreement $n^{\circ} 310220, H 2020$ CABRISS has received funding from the EU under grant agreement $n^{\circ} 641972$.

\section{Introduction}

A steady shift towards an increased use of renewable energy systems and reduction of hydrocarbon use is the target of the next decade. Despite strong promotion through support policies, this transition to renewables will be difficult and bear different challenges. Among these challenges are issues regarding optimization of energy saving and reduction of energy demand as well as the implementation of aesthetic energy solutions. Modern solar energy systems and materials seem to be a key factor in addressing these challenges. Especially photovoltaics integrated into buildings will presumably play an important role in future smart cities. Solar energy utilization occurs in the form of PV parks and PVs installed on building roofs and facades to create electrical power as well as in the form of solar thermal collectors to heat water and space (Sánchez-Pantoja et al., 2018). 


\section{Smart City Components:}

- smart environment

- mobility and infrastructure

- smart building technology

- citizen-friendly government

- open data

- digital citicens

- economic attractiveness

- resource friendly (contribution by H2020 CABRISS)

- efficient use of energy (contribution by FP7 SolarDesign)

Several studies underline the environmental advantages of photovoltaic energy generation (Wiser et al., 2016; Turney et al., 2011; Sánchez-Pantoja et al., 2018). In accordance with these studies, solar energy generally is perceived as a green and sustainable energy source, although the level of the user's environmental concern must be taken into account (Lu et al., 2018; Zhai et al., 2012). In the field of architecture, aesthetic aspects are of utmost importance in designing. Pure functionality is not always sufficient, as the form must follow both functional and aesthetic aspects. Acceptance by society is a definite prerequisite for a successful furtherance of solar energy as a key future energy source. (Zoellner et al., 2008). Especially in urban landscapes, a key decisive influence on the end consumer's preference is the visual appearance of the various options (Lu et al., 2018; Bao et al., 2017). Thus, it is necessary to bear in mind not only functional, but also aesthetic viewpoints when aiming to strengthen the use of PV.

\section{Methodology}

SolarDesign (On-the-fly alterable thin-film solar modules for design driven applications (Final Report Summary - FP7 SolarDesign, 2019), an FP7 project carried out with EUfunds, puts a focus on the development of flexible and easily used PV elements which utilize modern solar cell materials and newly evolved production processes. The project's outcome are novel printing and scribing methods allowing the manufacturing of flexible monolithically interconnected photovoltaic modules. These new monolithic interconnection technologies facilitate the manufacturing of thin-film PV modules. SolarDesign's new developments make on-the-fly alterations of the solar element's electrical properties possible. Furthermore, they allow extensive customization of the PV modules' shape, size and voltage. Through application of this technology, SolarDesign achieved to manufacture a solar foil with a width of $300 \mathrm{~mm}$, which allows curved solar cells with a minimal radius of $10 \mathrm{~mm}$.

The project addressed creative industries and adjacent industries alike. The creative industry receives novel materials and a new freedom-of-design for the development of solar powered products. The principal advantages of SolarDesign approach are: overcoming the square/rectangular solar module by using PV as a versatile building integrated component, improving the efficiency of the PV module by integrating in new morphologies, increasing the receiving surface by escaping from the concept of "optimal orientation" and increasing and improving the participation of the PV manufacturer in all the process. In addition to producing electricity, this kind of BIPV installations adds structural value and can enhance a building's aesthetic quality and design (colors, customization and at the same time remain cost competitive). Aesthetics and enhanced freedom of design are key stimulants for an increasing prevalence of Building-Integrated Photovoltaics (BIPVs).

CABRISS (H2020 project CABRISS, 2019) aims at stimulating a circular economy that manages the critical situation of recycling the significant volume of photovoltaic 
waste. The project aims to benefit also to electronics, metallurgy and glass industries by these means. The $\mathrm{H} 2020$ project CABRISS bundles the efforts of 16 European companies and research institutions. The project comprises the development of: (i) recycling technologies to recover In, Ag and Si for the sustainable PV technology and other applications; (ii) a solar cell processing roadmap, which will use Si waste for the high throughput, cost-effective manufacturing of hybrid Si based solar cells and aims at demonstrating the possibility for the re-usability and recyclability at the end of life of key PV materials. From the begin the CABRISS consortium decided to have all results in accordance with valid European standards to ease access to market.

\section{Results}

A PV driven street lamp was developed which illustrated the interdependence between design, standards and the resulting need for the minimum efficiency level of involved PV materials to guarantee the given luminescence. Shape and size of the street lamp's reflector define the aesthetic appearance. Thus, the diameter is limited to avoid a clumsy or bulky appearance. This restricted surface defines the available PV bearing area and consequently the affordable electrical energy which can be converted into light. SolarDesign had to solve the research problem to increase the efficiency of the PV material and especially its unfavourable temperature coefficient to guarantee the standardized luminescence in the street ("Road lighting" CEN/TR13201-1,2,3,4).

\section{Figure 1}

PV Driven Street Lamp - A compact concept is applied by SIARQ Advanced Solar Design to the solar streetlight: incorporation of the PV module, lithium-ion batteries, electronics and luminaire within a single, dome-shaped element, while keeping aesthetics and adaptation to the environment at a high level. The curved receptor surface maximizes PV production independently from the orientation.

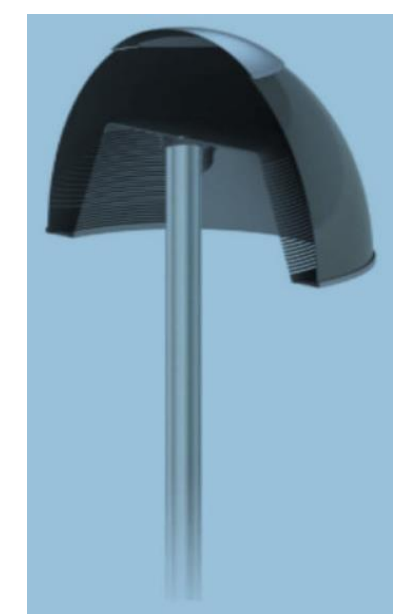

Source: Final Report Summary - FP7 SolarDesign, 2019; SIARQ Advanced Solar Design, 2019

The efficiency decreases of ZnS-buffered CIGS (Copper, Indium, Gallium, Diselenide) is smaller than for CaS-buffered CIGS. With further improvement of alternative buffers (like $\mathrm{ZnS}, \mathrm{ZnMgO}, \mathrm{Zn}(O, S)$ ), the efficiency values of CdS-buffered CIGS at $25^{\circ} \mathrm{C}$ can be reached. 
Figure 2

CABRISS' Materials for Further Use in the Recycling Process

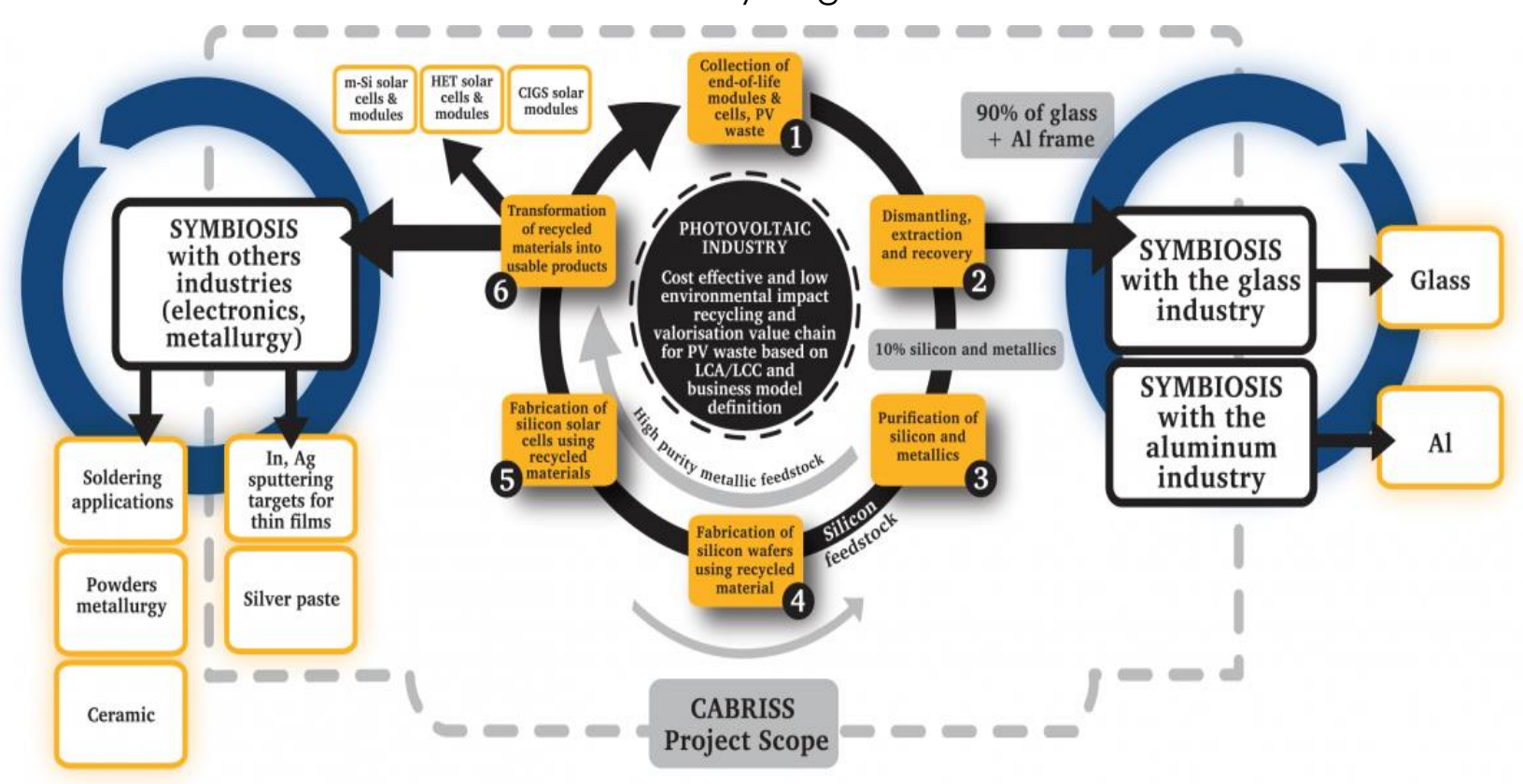

Source: (Brenner et al., 2017)

\section{Discussion}

Smart systems and control can allow energy usage optimization whilst guaranteeing optimal comfort, a healthy environment and numerous other services. Existing buildings could have high insulating envelopes to reduce energy use while achieving thermal comfort and aesthetic appearance. Materials for further use in the recycling process are mainly Si cell materials or valuable materials from thin film modules. After purification and pulverization, $\mathrm{Si}$ is used in different processes to provide crystalline $\mathrm{Si}$ ingots, hot pressed ingots, wafers or low-cost substrates with the following cell and module production. In a parallel pathway to the innovative c-Si PV production, the production of new thin film PV modules based on recycled materials and a roll-to-roll process was developed. The valuable materials like In or Ag which are an outcome of the recycling steps can be sold to the market or can be re-entered into the recycling process.

\section{Conclusion}

Two projects are presented which contributed to these requirements. CABRISS started the collection, de-pollution and treatment technologies for end-of-life PV as prerequisites for recovery and recycling. By proactive involving European standardization bodies, validity of results is guaranteed for the market. While growing photovoltaic (PV) panel waste embodies a new environmental challenge, it also bears unprecedented opportunities to create value and to open new economic paths. SolarDesign addressed the need for customized PV cells that are flexible and easy to integrate through the development of novel solar cell materials and manufacturing processes. SolarDesign developed new scribing and printing technologies that enable monolithically interconnected flexible solar modules. 


\section{References}

1. Bao, Q., Honda, T., El Ferik, S., Shaukat, M. M., Yang, M.C. (2017), "Understanding the Role of Visual Appeal in Consumer Preference for Residential Solar Panels", Renewable Energy, Vol. 113, pp. 1569-1579,

2. Brenner, W., Adamovic, N. (2017), "A Circular Economy for Photovoltaic Waste - the Vision of the European Project CABRISS", in the Proceedings of the 40th International Convention on Information and Communication Technology, Electronics and Microelectronics (MIPRO), Opatija, Croatia, IEEE, pp. 154-159,

3. Final Report Summary - FP7 SolarDesign (2016), "On-the-fly alterable thin-film solar modules for design driven applications", available at:

https://cordis.europa.eu/project/ren/105949/reporting/en (04 March 2019)

4. H2020 project CABRISS (2019), "Implementation of a Circular Economy Based on Recycling, Reused and Recovered Indium, Silicon and Silver Materials for Photovoltaic and Other Applications", available at: https://www.spire2030.eu/CABRISS (04 March 2019)

5. LU, M., Lin, A., Sun, J. (2018), "The Impact of Photovoltaic Applications on Urban Landscapes Based on Visual Q Methodology", Sustainability, Vol. 10, No. 4.

6. Sánchez-Pantoja, N., Vidal, R., Pastor, M. C. (2018), "Aesthetic Impact of Solar Energy Systems", Renewable and Sustainable Energy Reviews, Vol. 98, pp. 227-238.

7. SIARQ Advanced Solar Design (2019), available at: http://siara.com/en/ 104 March 2019)

8. Turney, D., Fthenakis, V. (2011), "Environmental Impacts from the Installation and Operation of Large-scale Solar Power Plants", Renewable and Sustainable Energy Reviews, Vol. 15, No. 6, pp. 3261-3270.

9. Wiser, R., Millstein, D., Mai, T., Macknick, J., Carpenter, A., Cohen, S. Cole, W., Frew, B., Heath, G. (2016), „The Environmental and Public Health Benefits of Achieving High Penetrations of Solar Energy in the United States", Energy, Vol. 113, pp. 472-486.

10. Zhai, P., Williams, E. (2012), "Analyzing Consumer Acceptance of Photovoltaics (PV) Using Fuzzy Logic Model", Renewable Energy, Vol. 41, pp. 350-357.

11. Zoellner, J., Schweizer-Ries, P., Wemhever, C. (2008), "Public Acceptance of Renewable Energies: Results from Case Studies in Germany", Energy Policy, Vol. 36, No. 11 , pp. 4136-4141.

\section{About the authors}

Werner Brenner, Asst. Prof. Dr., PhD (1986) TU Wien, Austria. He keeps about 140 records in MEMS. Reviewer/evaluator: EC: FP6, FP7, H2020;. He is experienced in cooperating with European standardization bodies: DIN, SEMI, CEN/CENELEC. The author can be contacted at werner.brenner@tuwien.ac.at.

Nadja Adamovic, Dr., MSc in Electrical Engineering (1993), PhD in Micro System Technologies at TU Wien (in 1996), with TU Vienna since 1994, Certificated Project Manager since 2005 and manager of EU and national projects, senior researcher at Institute of Sensor and Actuator Systems, having 20 years experience in MEMS (technologies and numerical modelling), participant in more than $20 \mathrm{EU}$ or national projects. For 7 years active in the field of renewable energies (photovoltaics and fuel cells). She is a member of the European Commission Advisory Group of the HORIZON 2020, LEIT (Nanotechnologies, Advanced Materials, Advanced Manufacturing and Processing). Dr. Adamovic is chairing the European Materials Modelling Council (EMMC). She is a member of the Austrian Photovoltaic Technology Platform, a member of the Council of the Faculty of Electrical Engineering and Information Technology, and a member of the Working Group for the Equal Opportunity and Gender Programmes at TU Wien. The author can be contacted at nadja.adamovic@łuwien.ac.at. 